\title{
47 各種検查用語と受聴明摬度に茼寸る考察
}

東京医科歯科大学倝科

語音㯖力検查が近代的な形で臨床に導入されて20年にもなるが、一般擥床用の語音聴力検查法においてさえ 現在なおいくかの問題卓が残つている。 test materialとして何が最通か，㛟榃の規格化に際し 検查方法をどの样に統制するか，測定值の信賴限界・幼監床的息義などが问題卓としてあげられ これらはお互に関連し合う複雑な因子によって支配されている。:ミではこれら関連する因子を

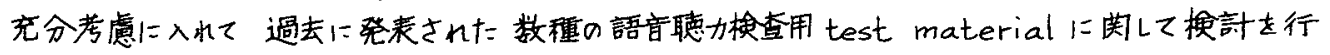
なった結果を登表する。

突験方法：今までに作られた日本語の無意単音節、有意

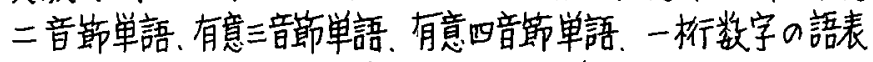
のうち8種をえらで、正常耳およで威音難㯖耳にこついて聴耳 検查を行なった。正常耳ではとくに減衰歪下、周波数歪下で、感 音難聴耳では最大明㖠度で各語表を比較した。アナウンサーは先の 突驗(Audiology.8；197，1965)によ川適当であるとされた女声(pitch:

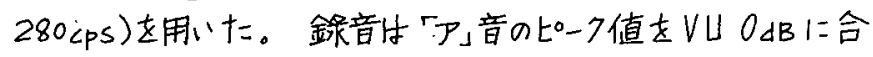
わせる梯にし、他の音は自然さをくずさ好样に発音させ、1000 cps の

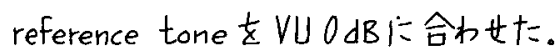

使用語音表: IA (無意単音䔮20語音表、本学会語音㯖力梌查法委員会案に よる) 音素棈成のみぼ会話頻出率に合わせたもの(PB)、简易検查女目的とした

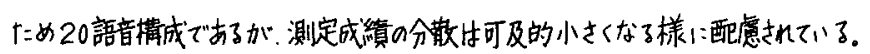

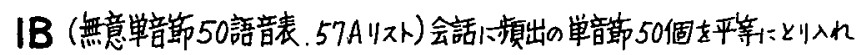
たものでPB楅成にはなっていない。以上の雨者は検亘のintroductionにおいて無意

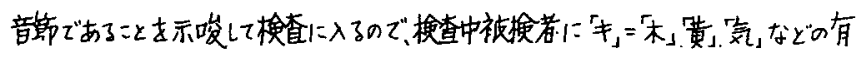

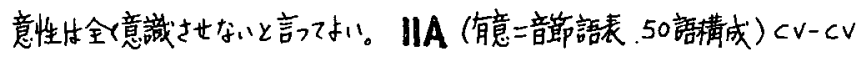
タイプのニ音蒒のこく平易な石詞のみから成子語表。PBでない。川B(有意二音節PB 語表，通研による）PBの概念に從がて䅦成抓、八礼音、ツな音引引音が含まれている。

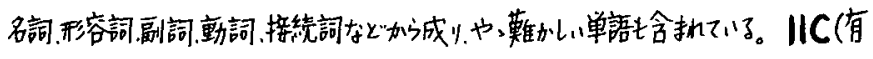

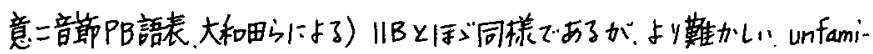
liarな刍語も含まれている。音素棈成でサ母音が比較的多く含屯。川 三音飠PB語表，通研による)川Bと同様にして作られた三音節单語の表。NA (有意四音㠌PB語表、大和田引によ子) 比較的familiarな語から成り，SRT梌查 用として作られた語表。N(一析数字語表、57A) 一析数字のう5良聴

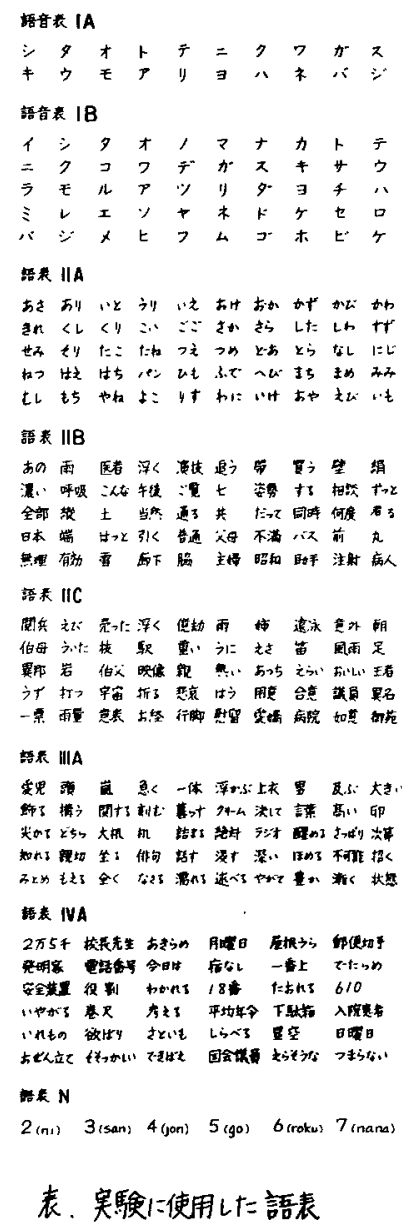

表、实験に使用した語表

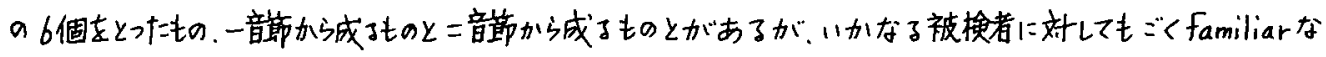
単語で、かつ出現する辟率が極度に限定された㭘查條件をつくる.SRTを测定するのが目的。

結果ならびに考按：実驗例数は充分々言之ないが得られた結果にフいて考察抺々。

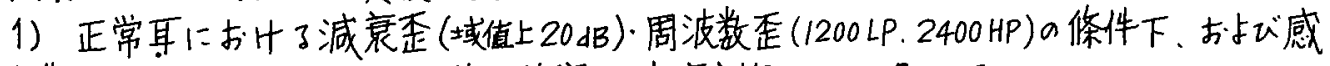
音難㯖耳のいずれにおいても単語(有意)は無意音節よりも了解し易い。 Audiology Vlo. 9, No. 2, 1966 
2）有意単語においては、その構 成音節数が増加するにつれて、あ る限度までは明暸度がよくなる傾 向がある。

3）二暗語諘においては川Aお よびしが比較的明暸度がよく 川Bが比較的悪い傾向を示した。 また川Cの測定結果のバラッキは 可成り大きかった。

4) 有意四音䔮語表は踣常に了 解し易くかフ間㟟之子埸合は 他の言葉に間营えるというょリは。 了解するかあるい忖全くからな いとい傾向を可す。

5) 一桁数字語表は以上の語 表のう最尘了解し易く、SRT測

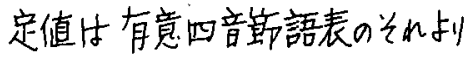
$5 \mathrm{~dB}$ 内外低<、純音平均聴力損 失值により近、傾问を示した。

無意音節ま㤢意語。有意語にあつては 音節数が增加するに從つて了解し易く な子傾向は今田の寒験においても認 められた。一般に考えられている様に:に は音䇾学的認知手が为川a增加上相ま口 て意味によよ認知手ががが明晻度さ支 えていると考えてチい思われる。宸密な意 味での比較牛团難であるが現在各国で用 いられている語音并别能力模亘用語表による 测定值に:てい我々(堀口:Intern. Aud. E, no.2) が先に調查した結果(国了)で同样。傾向 加晃られた。また無意音莭の測定值が有意 単語の光いに比しバラッキが特に大きくはない ので受聴能力の格差女明暸に測定す子意味

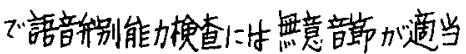

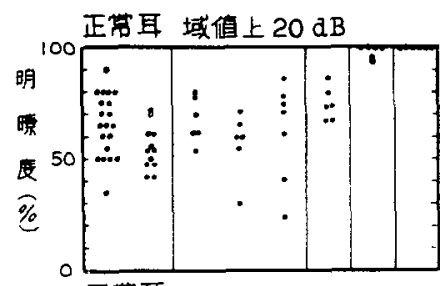

感音㬬㬝耳 Max.

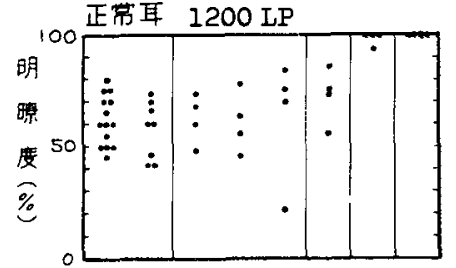

IA IB IIA IBB IIC UIA NA N

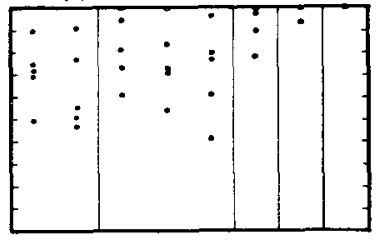

正常耳 $2400 \mathrm{HP}$

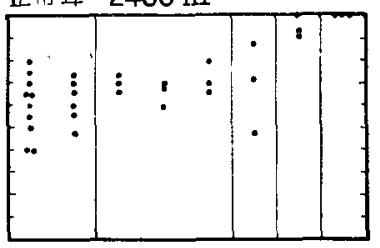

IA IB IIA IIB IIC IIAA IVA N

四1. 各種語表の種ての條件下での㯖取試駼結果

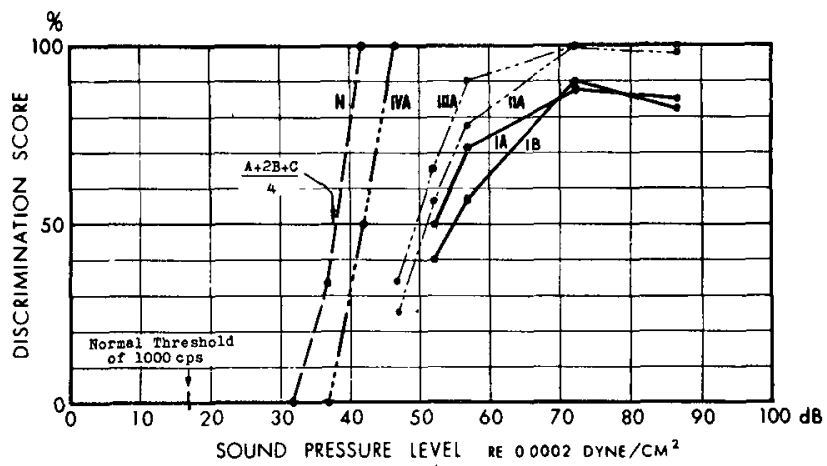

四2. 威昔性奞㯖耳(

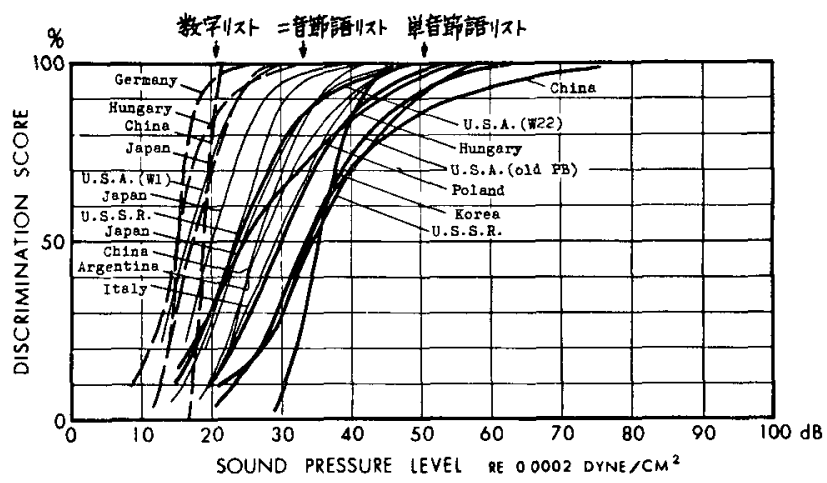

四3. 各国語梌查語表の正常耳によ子 score curve

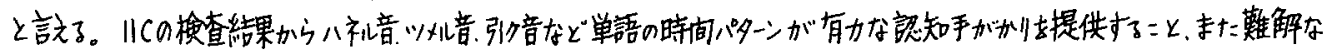

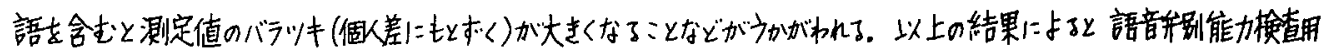

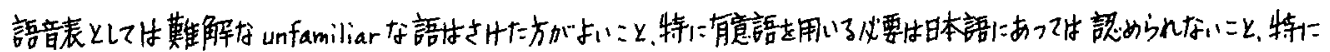

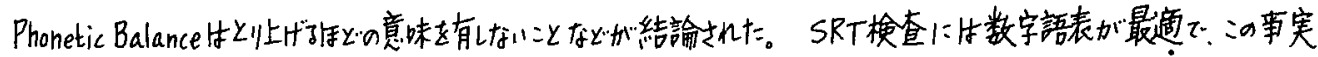
はこれを採用している外国でも同样な状態であることが認められた。 